\title{
The Significance of the Contralateral Testis Size Measurement with Ultrasonography in Predicting Monorchism in Boys with Nonpalpable Testicles
}

\section{Palpe Edilemeyen Testisli Çocuklarda Monoorşidizmi Öngörmede Ultrasonografiyle ÖIçülen Kontralateral Testis Boyutunun Önemi}

\author{
Çağrı Akın Şekerci', Yılören Tanıdır', Tarık Emre Şener', Ruslan Asadov², Ahmet Şahan'1, Tufan Tarcan', Ferruh Şimsek', Cem Akbal' \\ ${ }^{1}$ Marmara University Faculty of Medicine, Department of Urology, İstanbul, Turkiye \\ ${ }^{2}$ Marmara University Faculty of Medicine, Department of Radiology, istanbul, Turkiye
}

\section{What's known on the subject? and What does the study add?}

Previous studies have proven the relationship between testicular hypertrophy and undescended testis. However, these evaluations are done with a caliber and/or orchidometer, which are not quite accurate, compared to testicular ultrasonography. The present study investigated the utility of testicular ultrasonography and shown specificity and sensitivity levels of different contralateral testis diameter in predicting monorchism. Of all diameters, a contralateral testis greater than $20 \mathrm{~mm}$ can predict monorchism with an accuracy of $80 \%$ sensitivity and $83 \%$ specificity.

\begin{abstract}
Objective: The aim of this study was to determine the significance of contralateral testis size in predicting monorchism in pediatric patients with unilateral undescended testis.

Materials and Methods: The data of patients who underwent surgical operation by a single pediatric urologist for undescended testis between 2013 and 2016 was evaluated retrospectively. The patients were grouped as having monorchism (M), nonpalpable intra-abdominal testis (NPIAT), and palpable undescended testis (PUDT). The dimensions of the testes were measured ultrasonographically and recorded before operation. Patients with nonpalpable testis underwent diagnostic laparoscopy and patients with PUDT underwent inguinal orchiopexy.

Results: A total of 57 children with a mean age of 31 (11-60) months were evaluated. Of the children, 12 had M, 9 had NPIAT and 36 had PUDT with a similar mean age ( $>0.05)$. The size of the descended testis was found to be significantly small in NPIAT* and PUDT** groups compared to the M group $\left({ }^{*} p<0.05,{ }^{* *} p<0.001\right)$. However, the size of the undescended and descended testes was found to be similar between NPIAT and PUDT groups ( $p>0.05)$.
\end{abstract}

Conclusion: The size of the testis in the scrotum might help to localize the position of the undescended testis.

Keywords: Monorchism, nonpalpable intra-abdominal testis, palpable undescended testis, testis, ultrasonography

$0 ̈ z$

Amaç: Çalışmanın amacı tek taraflı inmemiş testisi olan çocuk hastalarda monoorşidizmin öngörüsünde kontralateral testis boyutunun öneminin değerlendirilmesidir.

Gereç ve Yöntem: 2013 ve 2016 yılları arasında kliniğimizde tek cerrah tarafından ameliyat edilen inmemiş testisi olan çocuk hastaların verileri retrospektif olarak değerlendirildi. Çocuklar monoorşidizm (M), intraabdominal palpe edilemeyen testis (IAPET) ve palpe edilebilen inmemiş testis (PEIT) olarak gruplandırılı. Uygulanan cerrahi yöntem öncesinde testis boyutları ultrasonografik olarak ölçüldü ve kaydedildi. Palpe edilemeyen testisi olan çocuklara tanısal laparoskopi, PEiT'si olan çocuklara inguinal orşiopeksi operasyonları uygulandı.

Correspondence: Cem Akbal MD, Marmara University Faculty of Medicine, Department of Urology, İstanbul, Turkiye

Phone: + 902166254768 E-mail: cakbal@gmail.com

Received: 14.02.2017 Accepted: 15.03.2017

Presented in: "13. Türk Çocuk Ürolojisi Kongresi" in Antalya on November 26-28, 2015.

Cite this article as: Şekerci ÇA, Tanıdır Y, Şener TE, Asadov R, Şahan A, Tarcan T, Şimşek F, Akbal C. The Significance of the Contralateral Testis Size

Measurement with Ultrasonography in Predicting Monorchism in Boys with Nonpalpable Testicles. J Urol Surg 2017;4:61-65.

๑Copyright 2017 by the Association of Urological Surgery / Journal of Urological Surgery published by Galenos Publishing House. 
Bulgular: Çalışmaya alınan 57 çocuğun yaş ortalaması 31 ay (11-60) olarak saptandı. Bu hastaların 12'si M, 9'u IAPET ve 36'sı PEiT olduğu izlendi ve yaş grupları arasında anlamlı bir fark saptanmadı $(p>0,05)$. M grubu ile IAPET grubu* ve PEIT grubu* arasında kontralateral testis boyu açısından anlamlı fark vardı $\left({ }^{*} p<0,05,{ }^{* *} p<0,001\right)$; ancak IAPET grubu ve PEIT grubu arasında kontralateral ve inmemiş testis boyutları açısından anlamlı fark saptanmadı $(p>0,05)$.

Sonuç: Skrotal testis boyutları inmemiş olan testisin lokalizasyonu ile ilgili bilgi verebilir.

Anahtar Kelimeler: Monoorşidizm, palpe edilemeyen intraabdominal testis, palpe edilebilen inmemiş testis, testis, ultrasonografi

\section{Introduction}

Undescended testis is one of the most common congenital defects in pediatric population. The overall incidence for undescended testis at birth is 3.7\% (1) and 1.1\% of these cases would persist up to the age of one year (2). Any children with undescended testis should be operated between 6 and 18 months of age $(3,4)$. If left untreated, fibrosis will occur $(5)$ which would lead to decrease in testicular size, and consequently to function lost. Thus, there are two major concerns in the treatment of undescended testis: increased risk for infertility and testicular malignancy $(6,7)$. Despite all the risks, orchiopexy is the gold standard treatment for undescended testis (5). Ultrasonography is not a reliable and efficient tool in the diagnosis of undescended testis (8). Diagnostic laparoscopy is suggested to be the best method for the diagnosis of undescended testis as it has the advantage of ease of use and flexibility, and high diagnostic accuracy $(9,10,11,12)$. Up to date, no study has shown the efficiency of physical findings in predicting the presence of the impalpable undescended testis. The present study aimed to evaluate the value of testis size in the scrotum in predicting the location of the contralateral testis in case of cryptorchidism.

\section{Materials and Methods}

Children who underwent surgical operation for undescended testis in the Department of Pediatric Urology at Marmara University, Faculty of Medicine between 2013 and 2016 were evaluated retrospectively. Medical chart of each child were recorded prospectively. A total of 57 consecutive prepubertal boys with unilateral undescended testis were evaluated. The cohort was divided into 3 groups according to the status of the undescended testis: monorchism (M), nonpalpable intra-abdominal testis (NPIAT), and palpable undescended testis (PUDT) (Figure 1). $\mathrm{M}$ is the state in which there are no testicular tissues on the undescended side. NPIAT is the state where testis cannot be palpated during the routine physical examination of the scrotum and inguinal channel but can be found inside the abdominal cavity during the laparoscopic exploration. PUDT is the state where the testis is not in the scrotal cavity but can be palpated during physical examination (13). Prior to any intervention, children were assessed with the aid of ultrasonography and inspections were done both for scrotum and for inguinal channels. The largest diameter of each descended and undescended testis was recorded. The largest diameter of each undescended testis was also measured by a surgical ruler at the time of the surgical intervention and, by this way, verification of the ultrasonographic measurements were done. Since there were no significant differences in diameter measurements between surgical ruler and ultrasonography driven ones, only the ultrasonographic measures are provided in the article. The surgical intervention choice was diagnostic laparoscopy in case of nonpalpable testis (M and NPIAT groups) and was inguinal orchiopexy in PUDT group.

\section{Statistical Analysis}

Statistical analyses were performed using the SPSS software version 20 (IBM Corp. Armonk, New York). Descriptive analyses were done and distribution of the variables were assessed by the Kolmogorov-Smirnov test. Age and testicular size did not show a normal distribution. Thus, comparisons between the groups were done using the Mann-Whitney $\mathrm{U}$ test. Data was provided as median (minimum-maximum) values. A p value of less than 0.05 was considered to indicate statistical significance.

\section{Results}

The number of children in M, NPIAT and PUDT groups was found to be 12,9 and 36 , respectively. The median age of the study cohort was found to be 31 months (11-60). Age and testicular diameter in each group are provided in Table 1. The median age of children within the M group, NPIAT group and PUDT group was 15 months (11-60), 25 months (11-60) and 36 months (11-

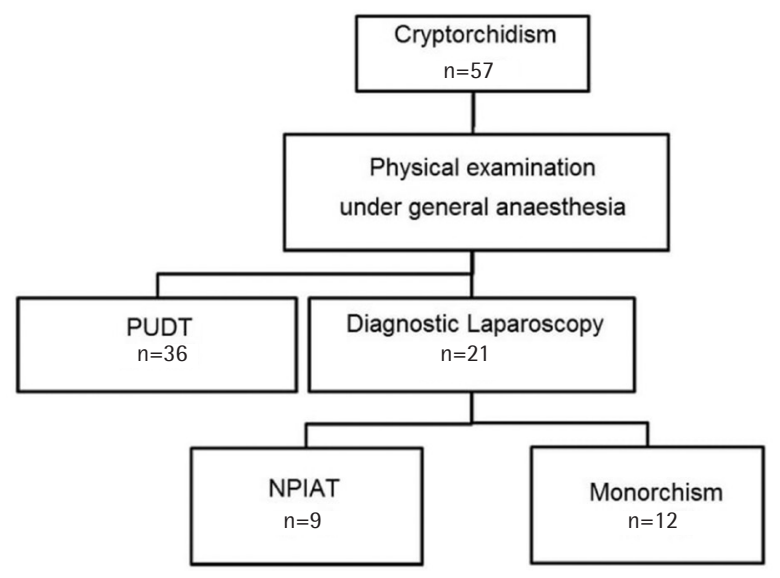

Figure 1. A flow diagram reflecting the process of patient selection PUDT: Palpable undescended testis, NPIAT: Nonpalpable intra-abdominal testis 
72), respectively. There was no statistically significant difference between the groups ( $p>0.05$ ). The median largest diameter of the undescended testis in NPIAT group and PUDT group was found to be $12 \mathrm{~mm}(11-19 \mathrm{~mm})$ and $14 \mathrm{~mm}(5-25)$, respectively and similar to age, no statistically significant difference was found between the two groups $(p>0.05)$. The median largest diameter of the descended testis in M group, NPIAT group and PUDT group was found to be $25 \mathrm{~mm}$ (19-36), $18 \mathrm{~mm}$ (13-24) and $16 \mathrm{~mm}$ (10$33)$, respectively. Interestingly, the median largest testicular size of the descended testis was found to be significantly greater in $\mathrm{M}$ than in NPIAT group $(\mathrm{p}<0.005)$ and PUDT group $(\mathrm{p}<0.001)$ (Table 1). However, no significant difference was observed in the largest testicular diameter of the descended testis between NPIAT and PUDT groups ( $p=0.458)$.

$\mathrm{M}$ was evaluated at various contralateral testicular diameters with the aid of ultrasound using a cut-off value of $18 \mathrm{~mm}$ $25 \mathrm{~mm}$. Each diameter's sensitivity and specificity levels are provided in Table 2.

\section{Discussion}

The present study evaluated the significance of the contralateral testis size measurement with the aid of ultrasonography in predicting $\mathrm{M}$ in boys with nonpalpable testicles, and found that the median contralateral testicular diameter to be significantly high in M compared to that in boys with NPIAT and PUDT. The median contralateral testicle length in boys with $M$ was $7 \mathrm{~mm}$ longer than that in boys with PUDT and was $9 \mathrm{~mm}$ longer that in boys with NPIAT.

Contralateral testicular hypertrophy phenomenon in $M$ in humans was initially proposed and proven by Laron and Zilka (14). They reported a significant increase in mean prepubertal testis volume in patients with $\mathrm{M}(3.75 \mathrm{~mL})$ compared to that in normal population $(1.64 \mathrm{~mL})$ with the aid of orchidometer and caliber (14). This significant difference in size remained up to age $(14,15,16)$. However, a testicular hypertrophy is not always a must in all patients with atrophic contralateral testis. The presence of a testis, related to the degree of atrophy, has been shown to have an impact on testicular hypertrophy. Koff (17) studied testicular size in undescended testis in 37 boys. He reported that patients with $M(n=12)$, descended normal testis $(n=19)$ and descended atrophic testis had the mean testis length of $2.22 \mathrm{~cm}, 1.51 \mathrm{~cm}$ and $1.78 \mathrm{~cm}$, respectively; and determined a diameter of $2 \mathrm{~cm}$ or a size of $2 \mathrm{cc}$ of testicular hypertrophy as a cut-off value for expecting $\mathrm{M}$ on contralateral side in children between 8 months and 3 years of age. On the contrary, Huff et al. (18) reported that the volume of the contralateral descended testis was not a reliable criterion for differentiating an absent testis from an intra-abdominal testis in a boy with a unilateral impalpable testis, since in their cohort of 109 children, 80\%

Table 1. Age (months) and diameter of the largest testicular size $(\mathrm{mm})$ is provided for each group $(\mathrm{mm})$ (Mann-Whitney U)

\begin{tabular}{llcc}
\hline & $\begin{array}{l}\text { Monorchism group } \\
(\mathbf{n}=12)\end{array}$ & $\begin{array}{l}\text { Nonpalpable intra-abdominal } \\
\text { testisgroup }(\mathbf{n = 9})\end{array}$ & $\begin{array}{l}\text { Palpable undescended testis } \\
\text { group }(\mathbf{n = 3 6 )}\end{array}$ \\
\hline Age (months) & $15(11-60)$ & $25(11-60)$ & $36(11-72)$ \\
Contralateral scrotal testis size $(\mathrm{mm})$ & $25(19-36)$ & $18(13-24)^{*}$ & $16(10-33)^{* *}$ \\
Undescended testis size $(\mathrm{mm})$ & - & $12(11-19)$ & $14(5-25)$ \\
\hline${ }^{*} p<0.005$ & & & \\
${ }^{* *} p<0.001$ & & & \\
\hline
\end{tabular}

Table 2. Sensitivity and specificity of contralateral compensatory testicular cut-off lengths to predict monorchism in boys with palpable undescended testis and nonpalpable intra-abdominal testis

\begin{tabular}{|c|c|c|c|c|c|c|}
\hline \multirow[t]{2}{*}{ Contralateral testis size } & \multicolumn{4}{|c|}{ Predicting monorchism } & \multirow[t]{2}{*}{ Sensitivity } & \multirow[t]{2}{*}{ Specificity } \\
\hline & TP & FP & FN & TN & & \\
\hline$\geq 18 \mathrm{~mm}$ & 12 & 13 & 0 & 32 & 1.00 & 0.71 \\
\hline$\geq 19 \mathrm{~mm}$ & 12 & 13 & 0 & 32 & 1.00 & 0.71 \\
\hline$\geq 20 \mathrm{~mm}$ & 10 & 9 & 2 & 36 & 0.83 & 0.80 \\
\hline$\geq 21 \mathrm{~mm}$ & 10 & 6 & 2 & 39 & 0.83 & 0.87 \\
\hline$\geq 22 \mathrm{~mm}$ & 10 & 5 & 2 & 40 & 0.83 & 0.89 \\
\hline$\geq 23 \mathrm{~mm}$ & 9 & 3 & 3 & 42 & 0.75 & 0.93 \\
\hline$\geq 24 \mathrm{~mm}$ & 9 & 3 & 3 & 42 & 0.75 & 0.93 \\
\hline$\geq 25 \mathrm{~mm}$ & 8 & 1 & 4 & 44 & 0.67 & 0.98 \\
\hline
\end{tabular}

TP: True positive, FP: False positive, FN: False negative, TN: True negative 
of monorchid patients ( $47 \%$ of all cohort) had a contralateral testicular size smaller than $2 \mathrm{~cm}$. However, they also found that the volume of the contralateral descended testis in boys with an absent testis was significantly greater than that in boys with intra-abdominal testes.

Several other authors proposed different cut-off values with different measurements methods, such as Takihara orchidometer, ruler and caliper, and introduced cut-off values of $1.8 \mathrm{~cm}(19,20), 2 \mathrm{~cm}(13,21)$ and 2 standard deviation above the normal mean volume (22) to predict monorchism. Our data has shown a sensitivity of 0.83 and a specificity of 0.80 for testicular diameter of $20 \mathrm{~mm}$ or more in diagnosing $\mathrm{M}$ with the help of ultrasonography (Table 2).

Most of the researchers preferred to use an orchidometer, ruler and caliper to determine testicular size as these methods are cheap and fast resulting ones. These methods are shown to be effective in testicular volume calculation and testicular size estimation, however, the best method in determining testicular size or volume is reported to be ultrasound (23). To our knowledge, this is the first study in the literature evaluating the relationship between testicular hypertrophy and undescended testis with ultrasound as the measurement tool. No standardization is available for the assessment of testicular measurements, and methods (21).

\section{Study Limitations}

The present study has two important limitations: retrospective design and relatively small number of patients. However, it is superior to the previous ones as the assessment method in size calculations was ultrasonography which is reported to be the best accurate tool. Since the data was not normally distributed and patient population was small, it is hard to suggest a cut-off value for testis size to predict monorchism.

\section{Conclusion}

A contralateral testicular diameter greater than and equal to 20 $\mathrm{mm}$ can predict $\mathrm{M}$ in boys with unilateral unpalpable testis with 80\% sensitivity and 83\% specificity. This finding can provide preoperative counseling and planning for appropriate surgical approach. Ultrasonography is a good and consistent tool in evaluating testis diameter. However, the present study cannot provide a better cut-off value for contralateral testicular diameter due to small sample size.

\section{Ethics}

Ethics Committee Approval: Retrospective study.

Informed Consent: Retrospective study.

Peer-review: Externally peer-reviewed.

\section{Authorship Contributions}

Surgical and Medical Practices: F.Ş., T.T., C.A., Ç.A.Ş., Concept: C.A., Ç.A.Ş., Design: C.A., Ç.A.Ş., Data Collection or Processing: Ç.A.Ş., Y.T., T.E.Ş., R.A., A.Ş., Analysis or Interpretation: Y.T., T.E.Ş., Literature Search: Ç.A.Ş., Y.T., T.E.Ş., Writing: Ç.A.Ş., Y.T.

Conflict of Interest: No conflict of interest was declared by the authors.

Financial Disclosure: The authors declared that this study received no financial support.

\section{References}

1. Thong $M$, Lim C, Fatimah $H$. Undescended testes: incidence in 1,002 consecutive male infants and outcome at 1 year of age. Pediatr Surg Int 1998;13:37-41.

2. Berkowitz GS, Lapinski RH, Dolgin SE, Gazella JG, Bodian CA, Holzman IR. Prevalence and natural history of cryptorchidism. Pediatrics 1993;92:44-49.

3. Hadziselimovic F, Herzog B. The importance of both an early orchidopexy and germ cell maturation for fertility. Lancet 2001;358:1156-1157.

4. Hadziselimovic F, Hocht B, Herzog B, Buser MW. Infertility in cryptorchidism is linked to the stage of germ cell development at orchidopexy. Horm Res 2007;68:46-52.

5. Park KH, Lee JH, Han JJ, Lee SD, Song SY. Histological evidences suggest recommending orchiopexy within the first year of life for children with unilateral inguinal cryptorchid testis. Int J Urol 2007;14:616-621.

6. Kollin C, Ritzen EM. Cryptorchidism: a clinical perspective. Pediatr Endocrinol Rev 2014;11(Suppl 2):240-250.

7. Lee PA, Coughlin MT. Fertility after bilateral cryptorchidism. Evaluation by paternity, hormone, and semen data. Horm Res 2001;55:28-32.

8. Abbas TO, Al-Shahwani N, Hayati A, Hady Samaha A, Bassiouny IE, Ali M. Role of ultrasonography in the preoperative assessment of impalpable testes: a single center experience. ISRN Urol 2012;2012:560216.

9. Holcomb GW 3rd, Brock JW 3rd, Neblett WW 3rd, Pietsch JB, Morgan WM 3rd. Laparoscopy for the nonpalpable testis. Am Surg 1994;60:143-147.

10. Park JH, Park YH, Park K, Choi H. Diagnostic laparoscopy for the management of impalpable testes. Korean J Urol 2011;52:355-358.

11. Ismail K, Ashour M, El-Afifi M, Hashish A, El-Dosouky N, Nagm M, Hashish M. Laparoscopy in the management of impalpable testis: series of 64 cases. World J Surg 2009;33:1514-1519.

12. Mehendale VG, Shenoy SN, Shah RS, Chaudhari NC, Mehendale AV. Laparoscopic management of impalpable undescended testes: 20 years' experience. J Minim Access Surg 2013;9:149-153.

13. Braga LH, Kim S, Farrokhyar F, Lorenzo AJ. Is there an optimal contralateral testicular cut-off size that predicts monorchism in boys with nonpalpable testicles? J Pediatr Urol 2014;10:693-698.

14. Laron Z, Zilka E. Compensatory hypertrophy of testicle in unilateral cryptorchidism. J Clin Endocrinol Metab 1969;29:1409-1413.

15. Joustra SD, van der Plas EM, Goede J, Oostdijk W, Delemarre-van de Waal HA, Hack WW, van Buuren S, Wit JM. New reference charts for testicular volume in Dutch children and adolescents allow the calculation of standard deviation scores. Acta Paediatr 2015;104:e271-278.

16. Goede J, Hack WW, Sijstermans K, van der Voort-Doedens LM, Van der Ploeg T, Meij-de Vries A, Delemarre-van de Waal HA. Normative values for testicular volume measured by ultrasonography in a normal population from infancy to adolescence. Horm Res Paediatr 2011;76:56-64. 
17. Koff SA. Does compensatory testicular enlargement predict monorchism? J Urol 1991;146:632-633.

18. Huff DS, Snyder HM 3rd, Hadziselimovic F, Blyth B, Duckett JW. An absent testis is associated with contralateral testicular hypertrophy. J Urol 1992;148:627-628.

19. Hurwitz RS, Kaptein JS. How well does contralateral testis hypertrophy predict the absence of the nonpalpable testis? J Urol 2001;165:588-592.

20. Snodgrass WT, Yucel S, Ziada A. Scrotal exploration for unilateral nonpalpable testis. J Urol 2007;178:1718-1721.
21. Hodhod A, Capolicchio JP, Jednak R, El-Sherbiny M. Testicular hypertrophy as a predictor for contralateral monorchism: Retrospective review of prospectively recorded data. J Pediatr Urol 2016;12:34.e1-5.

22. Mesrobian HG, Chassaignac JM, Laud PW. The presence or absence of an impalpable testis can be predicted from clinical observations alone. BJU Int 2002;90:97-99.

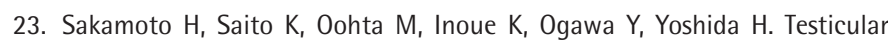
volume measurement: comparison of ultrasonography, orchidometry, and water displacement. Urology 2007;69:152-157. 